\title{
JC virus: A brief review
}

\author{
Basilio Vagner Ramírez ${ }^{1}$, Viviana Castaño Palacio ${ }^{2}$ \\ ${ }^{1}$ Medicarte, Multiple Sclerosis Program, Medellin, Colombia \\ ${ }^{2}$ Pablo Tobon Uribe Hospital, Medellin, Colombia \\ Email: Basilio_vagner@hotmail.com, vivipalacio173@hotmail.com
}

Received 23 February 2013; revised 23 March 2013; accepted 20 April 2013

Copyright (C) 2013 Basilio Vagner Ramírez, Viviana Castaño Palacio. This is an open access article distributed under the Creative Commons Attribution License, which permits unrestricted use, distribution, and reproduction in any medium, provided the original work is properly cited.

\begin{abstract}
Proportional to the growth rate of its clinical expression, the last decades have seen an increase on JC Virus diagnosis testing, and on therapeutic and symptoms management plans. Whether isolated or associated to retroviral therapy, the relationship of JC Virus to HIV allowed us to delve a little deeper into the knowledge of its behavior. Now as new immunemodulating and immune-suppressing therapies are developed, its clinical expression has become broader and more complexly, thereby our need is to develop more precise diagnosis and therapeutic plans.
\end{abstract}

Keywords: JC Virus; PLM; HIV; Monoclonal Antibodies

\section{INTRODUCTION}

Worldwide JC virus seroprevalence is 70\% - 90\% [1]. It is found in nature and 14 subtypes which can be isolated by specific geographic areas [2]. The virus infects children asymptomatically [3]; it remains on renal tissue and can be eliminated in urine in $40 \%-75 \%$ of individuals around the age of 30 [4,5]. Its coexistence with humans without much variation through centuries has made it a useful tool for geographic migration studies [6].

\section{PATHOPHYSIOLOGY}

This virus, without much variation, was isolated for the first time in 1971 on the brain of a Hodgkin lymphoma patient [7]. It is found associated to multiple diseases like medulloblastoma [8,9], multiform glioblastoma [10] and, Progressive Multifocal Leucoencephalopathy, an entity whose prevalence has increased during recent years and was first described by Åstrom in 1958 [11]. The JC virus or John Cunningham virus (JCV) is a polyomavirus with a circular double chain DNA $5 \mathrm{kB}$ genome, its capsid contains three viral proteins VP1, VP2 and VP3, with VP1 being the most abundant [12]. With a regulating protein (Agnoprotein) Progressive Multifocal Leucoencephalopathy (PML) pathogenesis is divided into 3 stages: during the first stage the virus behaves as a subclinical infection; during the second stage it remains latent in the genitourinary tract, bone marrow, tonsils, lung, spleen and gastrointestinal tissue [13-17] and during the third stage it presents viral reactivation and dissemination towards the central nervous system. During the second stage, the virus remains latent with a non- pathologic DNA regulatory region (RR) between codifying proteins, called archetype. Genetic material transcription takes place at the two DNA strands. The early region codifies the regulating proteins along with $\mathrm{T}$ protein and its variants (T135, T163 and T165). The latter region codifies the capsid proteins and the Agnoprotein [18]. Early genes are responsible for large $\mathrm{T}$ and small $\mathrm{t}$ antigen codification, and for the transformation, genetic regulation and replication. They codify counterclockwise while nonregulatory region or late genes codify clockwise.

Agnoprotein is a polypeptide which acts as cell proliferation and growth suppressor enabling second stage cell cycle deregulation. The Agnoprotein interacts with $\mathrm{T}$ protein to inhibit DNA replication [19]. The infectious cycle starts when JC Virus protein particles bind (SA) sialic acid related Alpha 2 - 6 cell receptors, and 5HT2A serotonin receptors [20]. Virions enter by way of clathrinmediated endocytosis [21].

Later, by way of a still unclear mechanism, viral DNA is transported to the nucleus. Following early viral genome expression, the viral transcription undergoes a series of changes before being carried to the cytoplasm for translation.

The big $\mathrm{T}$ antigens, small $\mathrm{t}$ antigens and $\mathrm{T}$ proteins (T135, T163 y T165) "Figure 1", are produced after early region transcription translation [22].

Big $\mathrm{T}$ antigens initiate viral DNA replication as well as 


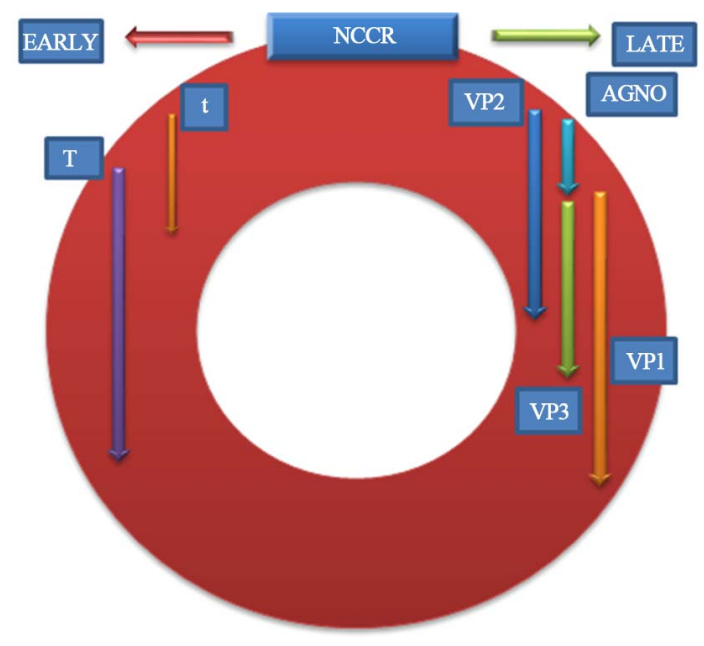

Figure 1. Viral protein synthesis.

the posterior activation [23].

Late transcription translation generates the Agnoprotein and the 3-capsid proteins, and then nucleus encapsidation begins. [24].

\section{DIAGNOSTIC TESTING}

The JC Virus is activated under different immunocompromised conditions and starts a demyelination process associated to oligodendroglial cells damage, a place where it multiplies and from where it subsequently emerges [25].

Among JC virus related to manifestations we have:

- Classic progressive multifocal and inflammatory Leucoencephalopathy(cPML-iPML) [26].

- Progressive multifocal Leucoencephalopathy associated to immune reconstitution syndrome (PML-IRIS) $[27,28]$.

- Progressive Multifocal Leucoencephalopathy associated to monoclonal antibodies (natalizumab, efalizumab, rituximab) [29-31].

- Virus C related cerebellar granular cells neuropathy (JCVGCN) [32].

- Meningitis (JCM) [33].

- JC virus related Encephalopathy (JCVE) [34].

\subsection{Diagnostic Approach}

The diagnosis of the different JC Virus related manifesttations are based on common elements.

PCR JCV sensitivity has decreased progressively after the antiretroviral therapy was developed and it is now deemed to be $58 \%$ [35].

Brain biopsy with pathological analysis has 64\% 96\% sensitivity and 100\% specificity [36].

Among the most outstanding PLM findings we have oligodendrocytes with extended nuclei, chromatin loss, and intranuclear accumulation of homogeneous baso- phile dyeing material.

Astrocyte morphology changes with mult-lobe hyperchromatic nuclei similar to neoplasic cells called "Bizarre" astrocytes.

Other characteristics are the absence of-or mild-inflammation [37].

The JC virus Neuronopathy of cerebellar granular cells (JCVGCN) describes cerebellar peduncles, bridge and cerebellar hemisphere as the expression of JC Virus without the characteristic findings on oligodendrocyte and astrocyte cells [38].

Neuropathy due to JC virus infection of the cerebellar granular cells (JCVGCN) is characterized by involvement of cerebellar peduncles, pons and cerebellar hemispheres as JCV expression without characteristic findings in oligodendrocytes and astrocytes [38].

Encephalopathy associated to JCV (JCVE) is characterized by lysis of the cortical pyramidal neurons, astrocytes and laminar necrosis. The findings might extend to the gray matter, without the typical demyelinating lesions [39].

A variant of the classic PML is pattern PLM or predominant inflammatory PML (iPML) of similar behavior but with a focal or diffuse predominant inflammatory component a perivascular mononuclear infiltrate, and CD3 cellular predominance [40].

In most cases big $\mathrm{T}$ antigen and VP1 capsid protein may be detected through immunohistochemistry on PML patients' brain tissue biopsies [41].

\subsection{Image Studies}

Currently image studies play a fundamental role on the diagnosis of the disease, considering resonance as its main representative [42]. There is predominant compromise of the cerebral white matter at different locations. (Supratentorial, infratentorial, medulla), [43,44], compromising somehow the gray matter, sometimes unusual locations such as the corpus callosum may also be involved [45].

It is characterized by classic hyperintense T2 and Flair and hyperintense T1 images, and isointense less frequently, may affect any area of the brain, usually the parietal lobe followed by the frontal lobe.

On MRI the classic lesions are characterized by being hiperintense on T2 and Flair imaging, hyperintense on T1 imaging and less frequently isointense. The lesions can affect any area of the brain, mainly the parietal lobe followed by the frontal lobe and the posterior fosse involving cerebellar hemispheres and peduncles. Lesions on the medulla are unusual [46]. Lesions tend to be asymmetrical, confluent and bilateral. The gray matter is involved especially at the thalamus and at basal ganglia [47]. Other techniques may also be used including magnetization by transfer [48] and spectroscopy [49]. 


\section{SYMPTOMATIC MANIFESTATIONS}

In general Symptoms tend to vary in relation to the location of the lesions; hemianopsia is one of the most frequent symptoms and it is present in $40 \%$ of cases. The patient might also have progressive decrease in muscular strength along with hemiparesis, ataxia and walking difficulties.

Cognitive deterioration is present in progressive manner and may lead to dementia [50].

Seizures may occur during the course of the disease or might be the first manifestation of disease [51].

\section{TREATMENT INVOLVED}

Several therapeutic regimes have been used to treat PLM and HIV patients with poor results up to now. Some of them involve application of mefloquine [52], cidofovir [53], mirtazapine [54], topotecan (topoisomerase inhibitor), interferon alpha [55] and citrabine [56].

One study with 4 types of antiretroviral medications, including enfuvirtide, suggested a possible increase in survival [57].

Approximately half of patients with HIV and PML survive after the initiation of antiretroviral therapy. However, the previous neurological deficiency may remain [58].

Plasma Exchange and immune absorption have been used on a PLM non- HIV patient [59].

\section{CONCLUSIONS}

In general, JCV symptomatic neurological expressions tend to increase progressively, not only on account of a larger number of cases involving HIV patients but due to the development of new therapeutic schemes focused on managing diverse pathologies that may affect in different ways the activity of the immune system.

The growing knowledge on JC Virus neural immune behavior patterns enable development of new diagnostic and therapeutic schemes focused on the early stages of the disease, even before related to clinical manifestations appear, taking into account the great current therapeutic limitations, especially PML cases in conjunction with HIV.

\section{REFERENCES}

[1] Padgett, B.L. and Walker, D.L. (1973) Prevalence of antibodies in human sera against JC virus, an isolate from a case of progressive multifocal Leucoencephalopathy. The Journal of Infectious Diseases, 127, 467-470. doi:10.1093/infdis/127.4.467

[2] Boukoum, H., Nahdi, I., Abid, N., Foulongne, V., Sahtout, W., Zallema, D., Skiri, H., Aloui, S., Achour, A., Segondy, M. and Aouni, M. (2012) Distribution of JC polyomavi- rus genotypes in Tunisian renal transplant recipients between January 2008 and January 2011. Journal of Medical Virology, 84, 1818-1824. doi:10.1002/jmv.23385

[3] Kunitake, T., Kitamura, T., Guo, J., Taguchi, F., Kawabe, K. and Yogo, Y. (1995) Parent-to-child transmission is relatively common in the spread of the human polyomavirus JC virus. Journal of Clinical Microbiology, 33, 1448-1451

[4] Agostini, H.T., Ryschkewitsch, C.F. and Stoner, G.L. (1996) Genotype profile of human polyomavirus JC excreted in urine of immunocompetent individuals. Journal of Clinical Microbiology, 34, 159-164.

[5] Kitamura, T., Aso, Y., Kuniyoshi, N., et al. (1990) High incidence of urinary JC virus excretion in nonimmunosuppressed older patients. The Journal of Infectious Diseases, 161, 1128-1133. doi:10.1093/infdis/161.6.1128

[6] Sugimoto, C., Kitamura, T., Guo J., Al-Ahdal, M.N., Shchelkunov, S.N., Otova, B., Ondrejka, P., Chollet, J.Y., El-Safi, S., Ettayebi, M., Gresenguet, G., Kocagoz, T., Chaiyarasamee, S., Thant, K.Z., Thein, S., Moe, K., Ko-bayashi, N., Taguchi, F. and Yogo, Y. (1997) Typing of urinary JC virus DNA offers a novel means of tracing human migrations. Proceedings of the National Academy of Sciences of the United States, 94, 9191-9196. doi:10.1073/pnas.94.17.9191

[7] Padgett, B.L., Walker, D.L., ZuRhein, G.M., et al. (1971) Cultivation of papova-like virus from human brain with progressive multifocal leucoencephalopathy. Lancet, 29, 1257-1260. doi:10.1016/S0140-6736(71)91777-6

[8] Khalili, K., Krynska, B., Del Valle, L., Katsetos, C. and Croul, S. (1999) Medullobas, toma and the human neurotropic polyomavirus JC virus. Lancet, 353, 1152-1153. doi:10.1016/S0140-6736(99)00357-8

[9] Krynska, B., Del Valle, L., Croul, S., Gordon, J., Katsetos, C.D., Carbone, M., Giordano, A. and Khalili, K. (1999) Detection of human neurotropic JC virus DNAsequence and expression of the viral oncogenic protein in pediatric medulloblastomas. Proceedings of the National Academy of Sciences of the United States, 96, 11519-11524. doi:10.1073/pnas.96.20.11519

[10] Del Valle, L., Azizi, S.A., Krynska, B., Enam, S., Croul, S.E. and Khalili, K. (2000) Reactivation of human neurotropic JC virus expressing oncogenic protein in a recurrent glioblastomamultiforme. Annals of Neurology, 48, 932-936.

doi:10.1002/1531-8249(200012)48:6<932::AID-ANA15 $>3.0 . \mathrm{CO} ; 2-\mathrm{E}$

[11] Åström, K.E., Mancall, E.L. and Richardson, E.P. (1958) Progressive multifocal leukoencephalopathy: A hitherto unrecognized complication of chronic lymphatic leukaemia and Hodgkin's disease. Brain, 81, 93-111.

[12] Goldmann, C., Stolte, N., Nisslein, T., et al. (2000) Packaging of small molecules into VP1-virus-like particles of the humanpolyomavirus JC virus. Journal of Virological Methods, 90, 85-90. doi:10.1016/S0166-0934(00)00226-3

[13] Tan, C.S., Dezube, B.J., Bhargava, P., et al. (2009) Detection of JC virus DNAand proteins in the bone marrow of HIV-positive and HIV-negative patients: Implications for viral latency and neurotropic transformation. The 
Journal of Infectious Diseases, 199, 881-888. doi:10.1086/597117

[14] Weber, T. (2008) Progressive multifocal leukoencephalopathy. Neurologic Clinics, 26, 833-854. doi:10.1016/j.ncl.2008.03.007

[15] Elsner, C. and Dörries, K. (1998) Human polyomavirus JC control region variants in persistently infected CNS and kidney tissue. Journal of General Virology, 179, 789799.

[16] Frisque, R.J., Bream, G.L. and Cannella, M.T. (1984) Human polyomavirus JC virus genome. Journal of Virology, 51, 458-469.

[17] Vaz, B., Cinque, P., Pickhardt, M. and Weber, T. (2000) Analysis of the transcriptional control region in progressive multifocal leukoencephalopathy. Journal of NeuroVirology, 6, 398-409. doi:10.3109/13550280009018304

[18] Chang, D., Fung, C.Y., et al. (1997) Self-assembly of the JC virus major capsid protein, VP1, expressed in insect cells. Journal of General Virology, 78, 1435-1439.

[19] Sariyer, I.K., Khalili, K. and Safak, M. (2008) Dephosphorylation of JC virus agnoprotein by protein phosphatase 2A: Inhibition by small t antigen. Virology, 375, 464-479. doi:10.1016/j.virol.2008.02.020

[20] Atwood, W.J., Amemiya, K., Traub, R., Harms, J. and Major, E.O. (1992) Interaction of the human polyomavirus, JCV, with human Blymphocytes. Virology, 190, 716723. doi:10.1016/0042-6822(92)90909-9

[21] Edeling, M.A., Smith, C. and Owen, D. (2007) Life of a clathrin coat: Insights from clathrin and AP structures. Nature Reviews. Molecular Cell Biology, 7, 32-44.

[22] Akan, I., Sariyer, I.K., Biffi, R., Palermo, V., Woolridge, S., White, M.K., Amini, S., Khalili, K. and Safak, M. (2006) Human polyomavirus JCV late leader peptide region contains important regulatory elements. Virology, 349, 66-78. doi:10.1016/j.virol.2006.01.025

[23] Frisque, R.J., Hofstetter, C. and Tyagarajan, S.K. (2006) Transforming activities of JC virus early proteins. Advances in Experimental Medicine and Biology, 577, 288309. doi:10.1007/0-387-32957-9_21

[24] Suzuki, T., Semba, S., Sunden, Y., Orba, Y., Kobayashi, S., Nagashima, K., Kimura, T., Hasegawa, H. and Sawa, H. (2012) Role of JC virus agnoprotein in virion formation. Microbiology and Immunology, 56, 639-646. doi:10.1111/j.1348-0421.2012.00484.x

[25] Johnson, R.T. and Major, E.O. (2004) Infectious demyelinating diseases. In: Lazzarini, R., Ed., Myelin Biology and Disorders, Vol. 2. Elsevier Academic Press, Waltham, 953-983.

[26] Brew, B.J., Davies, N.W., Cinque, P., et al. (2010) Progressive multifocal leukoencephalopathy and other forms of JC virus disease. Nature Reviews Neurology, 6, 667679. doi:10.1038/nrneurol.2010.164

[27] Tan, K., Roda, R., Ostrow, L., et al. (2009) PMl-IRIS in patients with HIV infection. Neurology, 72, 1458-1464. doi:10.1212/01.wnl.0000343510.08643.74

[28] Cinque, P., Bossolasco, A.S., Brambilla, A.M., et al. (2003) The effect of highly active antiretroviral therapyinduced immune reconstitution on development and out- come of progressive multifocal leukoencephalopathy: Study of 43 cases with review of the literature. Journal for Neurovirology, 9, 1-8.

[29] Linda, H., von Heijne, A., Major, E.O., Ryschkewitsch, C., Berg, J., Olsson, T., et al. (2009) Progressive multifocal leukoencephalopathy after natalizumabmonotherapy. The New England Journal of Medicine, 361, 1081-1087. doi:10.1056/NEJMoa0810316

[30] Wenning, W., Haghikia, A., Laubenberger, J., Clifford, D.B., Behrens, P.F., Chan, A., et al. (2009) Treatment of progressive multifocal leukoencephalopathy associated with natalizumab. The New England Journal of Medicine, 361, 1075-1080. doi:10.1056/NEJMoa0810257

[31] Berger, J. (2010) Progressive Multifocal Leukoencephalopathy and Newer Biological Agents. Drug Safety, 33, 969-983. doi:10.2165/11537510-000000000-00000

[32] Koralnik, I., Wüthrich, C., Dang, X., Rottnek, M., Gurtman, A., Simpson, D., et al. (2005) JC Virus Granule Cell Neuropathy: A Novel Clinical Síndrome Distinct from Progreesive Multifocal Leukoencephalopathy. Annals of Neurology, 57, 576-580. doi:10.1002/ana.20431

[33] Viallard, J.F., Ellie, E., Lazaro, E., et al. (2005) JC virus meningitis in a patient with systemic lupus erythematosus. Lupus, 14, 964-966. doi:10.1191/0961203305lu2229cr

[34] Tan, C.S. and Koralnik, I.J. (2010) Progressive multifocal leukoencephalopathy and other disorders caused by JC virus: Clinical features and pathogenesis. The Lancet Neurology, 9, 425-437. doi:10.1016/S1474-4422(10)70040-5

[35] Marzocchetti, A., Di Giambenedetto, S., Cingolani, A., et al. (2005) Reduced rate of diagnostic positive detection of JC virus DNA in cerebrospinal fluid in cases of suspected progressive multifocal leukoencephalopathy in the era of potentantiretroviral therapy. Journal of Clinical Microbiology, 43, 4175-4177. doi:10.1128/JCM.43.8.4175-4177.2005

[36] Skolasky, R.L., Dal Pan, G.J., Olivi, A., et al. (1999) HIVassociated primary CNS morbidityand utility of brain biopsy. Journal of the Neurological Sciences, 163, 32-38. doi:10.1016/S0022-510X(98)00315-3

[37] Richardson Jr., E.P. (1961) Progressive multifocal leukoencephalopathy. The New England Journal of Medicine, 265, 815-823. doi:10.1056/NEJM196110262651701

[38] Roux, D., Bouldouyre, M.A., Mercier-Delarue, S., Seilhean, D., Zagdanski, A.M., Delaugerre, C., Simon, F., Molina, J.M. and Legoff, J. (2011) JC virus variant associated with cerebellar atrophy in a patient with AIDS. Journal of Clinical Microbiology, 49, 2196-2199. doi:10.1128/JCM.02057-10

[39] Tallantyre, E.C., Paine, S.M., Sharp, C.P., Lowe, J.S., Gran, B. (2009) Atypical progressive multifocal leukoencephalopathy associated with an unusual JC polyomavirus mutation. JAMA Neurology, 66, 1021-1024. doi:10.1001/archneurol.2009.94

[40] Huang, D., Cossoy, M., Li, M., et al. (2007) Inflammatory progressive multifocal leukoencephalopathy in human immunodeficiency virus-negative patients. Annals of Neurology, 62, 34-39. doi:10.1002/ana.21085

[41] Tan, C.S., Ellis, L.C., Wüthrich, C., et al. (2010) JC virus 
latency in the brain and extraneural organs of patients with and without progressive multifocal leukoencephalopathy. Journal of Virology, 84, 9200-9209. doi:10.1128/JVI.00609-10

[42] Port, J.D., Miseljic, S., Lee, R.R., et al. (1999) Progressive multifocal leukoencephalopathy demonstrating contrast enhancement on MRI and uptake of thallium-201: A case report. Neuroradiology, 41, 895-898. doi:10.1007/s002340050862

[43] Takeda, S., Yamazaki, K., Miyakawa, T., et al. (2009) Progressive multifocal leukoencephalopathy showing extensive spinal cord involvement in a patient with lymphocytopenia. Neuropathology, 29, 485-493. zdoi:10.1111/j.1440-1789.2008.00981.x

[44] Sarrazin, J.L., Soulié, D., Derosier, C., Lescop, J., Schill, H. and Cordoliani, Y.S. (1995) MRI aspects of progresssive multifocal leukoencephalopathy. Journal of Neuroradiology, 22, 172-179.

[45] Bourekas, E.C., Varakis, K., Bruns, D., Christoforidis, G.A., Baujan, M., Slone, H.W. and Kehagias, D. (2002) Lesions of the corpus callosum: MR imaging and differential considerations in adults and children. American Journal of Roentgenology, 179, 251-257. doi:10.2214/ajr.179.1.1790251

[46] Trotot, P.M., Vazeux, R., Yamashita, H.K., et al. (1990) MRI pattern of progressive multifocal leukoencephalopathy (PML) in AIDS: Pathological correlations. Journal of Neuroradiology, 17, 233-254.

[47] Sweeney, B.J., Manji, H., Miller, R.F., et al. (1994) Cortical and subcortical JC virus infection: Two unusual cases of AIDS associated progressive multifocal leukoencephalopathy. Journal of Neurology, Neurosurgery \& Psychiatry, 57, 994-997. doi:10.1136/jnnp.57.8.994

[48] Menon, D.K., Ainsworth, J.G., Cox, I.J., et al. (1992) Proton MR spectroscopy of the brain in AIDS dementia complex. Journal of Computer Assisted Tomography, 16, 538-542. doi:10.1097/00004728-199207000-00007

[49] Arvik, J.G., Lenkinski, R.E., Grossman, R.I., et al. (1993) Proton MR spectroscopy of HIV infected patients: Characterization of abnormalities with imaging and clinical correlation. Radiology, 186, 739-744.

[50] Manji, H. and Miller, R.F. (2000) Progressive multifocal leucoencephalopathy: Progress in the AIDS era. Journal of Neurology, Neurosurgery \& Psychiatry, 69, 569-571. doi:10.1136/jnnp.69.5.569
[51] Fontoura, P., Vale, J., Lima, C., Scaravilli, F. and Guimarães, J. (2002) Progressive myoclonic ataxia and JC virus encephalitis in an AIDS patient. Journal of Neurology, Neurosurgery \& Psychiatry, 72, 653-656. doi:10.1136/jnnp.72.5.653

[52] Adachi, E., Koibuchi, T., Imai, K., Kikuchi, T., Koga, M., Nakamura, H., Miura, T., Iwamoto, A. and Fujii, T. (2012) Favourable outcome of progressive multifocal leukoencephalopathy with mefloquine treatment in combination with antiretroviral therapy in an HIV-infected patient. International Journal of STD \& AIDS, 23, 603-605. doi:10.1258/ijsa.2012.011305

[53] De Luca, A., Ammassari, A., Pezzotti, P., et al. (2008) Cidofovir in addition to antiretroviral treatment is not effective for AIDS-associated progressive multifocal leukoencephalopathy: A multicohort analysis. AIDS, 22, 1759-1767. doi:10.1097/QAD.0b013e32830a5043

[54] Verma, S., Cikurel, K., Koralnik, I.J., et al. (2007) Mirtazapine in progressive multifocal leukoencephalopathy associated with polycythemia vera. The Journal of Infectious Diseases, 196, 709-711. doi:10.1086/520514

[55] Huang, S.S., Skolasky, R.L. and Dal Pan, G.J. (1998) Survival prolongation in HIV-associated progressive multifocal leukoencephalopathy treated with alpha-interferon: An observational study. Journal of Neuroradiology, 4, 324-332. doi:10.3109/13550289809114533

[56] Hall, C.D., Dafni, U., Simpson, D., et al. (1998) Failure of cytarabine in progressive multifocal leukoencephalopathy associated with human immunodeficiency virus infection. The New England Journal of Medicine, 338, 1345-1351. doi:10.1056/NEJM199805073381903

[57] Gasnault, J., Hendel Chavez, E., et al. (2007) Acceleration of immune recovery on intensified ART improves survival in patients with AIDS-related PML: Preliminary reports of the ANRS 125 Trial. 14th Conference on Retroviruses and Opportunistic Illnesses, Los Angeles.

[58] Clifford, D.B., Yiannoutsos, C., Glicksman, M., et al. (1999) HAART improves prognosis in HIV-associated progressive multifocal leukoencephalopathy. Neurology, 52, 623-625. doi:10.1212/WNL.52.3.623

[59] Wenning, W., Haghikia, A., Laubenberger, J., Clifford, D.B., Behrens, P.F., Chan, A. and Gold, R. (2009) Treatment of progressive multifocal leukoencephalopathy associated with natalizumab. The New England Journal of Medicine, 361, 1075-1080. doi:10.1056/NEJMoa0810257 